\title{
Analysis of PONV incidence in gynaecology patients*
}

\author{
Dorota Ćwiek ${ }^{1, A} \bowtie$, Arleta Wojciechowska², Katarzyna Szymoniak ${ }^{1, B}$, Dorota Fryc ${ }^{1, c}$, Marta Stanisz ${ }^{3}$, \\ Janusz Menkiszak' ${ }^{2, D}$
}

${ }^{1}$ Pomeranian Medical University in Szczecin, Independent Laboratory of Obstetrics, Żołnierska 48, 71-210 Szczecin, Poland

2 Independent Public Clinical Hospital No. 2 of the Pomeranian Medical University in Szczecin, Surgical Gynaecology and Gynaecological Oncology Clinic for Adults and Girls, Powstańców Wlkp. 72, 70-111 Szczecin, Poland

${ }^{3}$ Pomeranian Medical University in Szczecin, Department of Procreative Health, Żołnierska 48, 71-210 Szczecin, Poland

A ORCID: 0000-0002-4908-9056; $\quad{ }^{B}$ ORCID: 0000-0003-3941-7340; C ORCID: 0000-0002-9014-7510; ${ }^{D}$ ORCID: 0000-0001-8279-7196

$\triangle$ dorota.cwiek@pum.edu.pl

\begin{abstract}
Introduction: Postoperative nausea and vomiting (PONV) is the most common side effect of anaesthesia, as reported by patients in the postoperative period. The overall incidence of PONV, according to various authors, is in the $8-92 \%$ range. The latest research on the pathophysiology of vomit reflexes has played an important role in changing the perception of PONV and introduction of PONV prevention, which significantly improves patient comfort by reducing the number of complications and shortening the length of the hospital stay.

The aim of the study was to analyse the incidence of PONV in gynaecological patients.

Materials and methods: The study was conducted among 300 women, patients of the Surgical Gynaecology and Gynaecological Oncology Clinic for Adults and Girls at the Independent Public Clinical Hospital No. 2 of the Pomeranian Medical University in Szczecin, who underwent surgery due to a variety of gynaecological conditions in the period from May to October 2015. The research tool was the author's own questionnaire containing 22 closed-ended questions. The questionnaire included demographics as well as an assessment of the state of the women's health in terms of complications (nausea, vomiting), and substance use (tobacco, alcohol). Patient medical records were also analysed. Results: The results demonstrated: 1) no relationship between the socio-demographic variables and the incidence of nausea and
\end{abstract}

vomiting in the postoperative period; 2) no relationship between PONV and specific medical variables, such as alcohol use, body mass index (BMI), administration of opioids such as fentanyl and fentanyl plus morphine; 3 ) a relationship between the type of surgery, anaesthesia used, smoking, and the incidence of nausea and vomiting; 4) a high risk of nausea and vomiting in patients after administration of spinal morphine into the subarachnoid space; 5) metabolic diseases, diseases of the lower digestive tract, respiratory conditions, and motion sickness had a negative influence on the incidence of PONV.

Conclusions: 1 . The type and duration of surgery as well as the type of anaesthesia and opioids used affected the incidence of nausea and vomiting in the postoperative period. If possible, every effort should be made to shorten the duration of surgery, perform surgery laparoscopically and administer drugs, which do not affect the incidence of nausea and vomiting. 2 . There is a need for organisational changes in hospitals regarding the introduction and compliance with ERAS, in particular, with regard to the withdrawal of food and drink before surgery. 3. The use of chewing gum strongly reduced the incidence of nausea and vomiting. Therefore, it would be important to introduce, as a standard practice, this non-pharmacological prevention method in the postoperative period.

Keywords: nausea; vomiting; PONV; prevention; gynaecology; risk factors.

\section{INTRODUCTION}

Postoperative nausea and vomiting (PONV) is the most common side effect of anaesthesia, as reported by patients in the postoperative period. The overall incidence of PONV, according to various authors, is in the $8-92 \%$ range [1]. Postoperative nausea and vomiting can lead to numerous complications, including dehydration, electrolyte imbalance, venous pressure increase, bleeding or breaking of sutures or aspiration pneumonia. As a result, these complications increase the length of hospital stay, significantly increasing the costs of medical care and reducing patient satisfaction $[2,3]$.

The latest research on the pathophysiology of vomit reflexes has played an important role in changing the perception of PONV and the introduction of PONV prevention, which significantly improves patient comfort by reducing the number of complications and shortening the length of the hospital stay [4]. Despite all the research and reports, it is difficult to find a "golden means" in preventing the incidence of PONV. However, predicting PONV should always be taken into account when planning anaesthesiological management, whereas prevention, prophylaxis and treatment should be standard in everyday practice.

The aim of the study was to analyse the incidence of PONV in gynaecological patients.

\section{MATERIALS AND METHODS}

The study was conducted among 300 women, patients of the Surgical Gynaecology and Gynaecological Oncology Clinic for Adults and Girls at the Independent Public Clinical Hospital

\footnotetext{
*This article is based on thesis titled "Analysis of PONV incidence in gynaecological patients" by Arleta Wojciechowska, presented on Faculty of Health Sciences of Pomeranian
} Medical University in Szczecin. Thesis supervisor: MD Dorota Ćwiek. The original contains: 92 pages, 36 tables, 28 drawings and 98 bibliography items. 
No. 2 of the Pomeranian Medical University in Szczecin, who underwent surgery due to a variety of gynaecological conditions in the period May to October 2015.

The data collection method adopted was a diagnostic survey containing 22 closed-ended questions and medical record analysis. The questionnaire covered demographics as well as an assessment of the state of the women's health in terms of complications (nausea, vomiting), and substance use (tobacco, alcohol). Based on the acquired data, body mass index (BMI) was calculated. Analysis of the anaesthetics records helped to determine the type of anaesthesia and surgery, its duration, the pharmacotherapy during anaesthesia, the prevention of PONV and the duration of withdrawal of food and drink during the perioperative period. Data concerning medical history, including the symptoms of PONV, was collected prior to surgery. The assessment of patient well-being, including the perioperative factors, was made the 1st day after surgery.

Analysis of the results was conducted using PQStat ver 1.6. Dichotomic variables were characterised by the relative number and frequency (\%) of occurrence of a particular characteristic. The frequency of differences between relative occurrence frequencies of each qualitative variable was assessed using $\chi^{2}$ test. The significance level (p) equaled 0.05 (acceptable type I error). The classification of significance levels was as follows: $p>0.05$ - statistically non-significant difference or correlation, $p<0.05$ - statistically significant difference or correlation.

\section{RESULTS}

Table 1 shows the socio-demographic and health data of the respondents. The majority lived in a city (80.67\%). Most women had secondary school education (40.66\%), 29.67\% had vocational education and $29.67 \%$ had higher education. The majority of women were in a relationship (75.0\%). More than half of the respondents (62.34\%) were characterised by good economic status. A satisfactory financial situation was reported by $25.33 \%$ of the patients, $8.33 \%$ of them said their economic status was very good and $4.0 \%$ described it as unsatisfactory. Over a quarter of the respondents $(26.0 \%)$ were addicted to smoking tobacco. Most of them declared occasional alcohol consumption (76.34\%), while $23.0 \%$ abstained from drinking.

Only $38.33 \%$ of the respondents were not burdened with additional health conditions. The most common ailments were cardiovascular diseases (40.0\%) and endocrine disorders (15.0\%). Additionally, $12.7 \%$ of the patients suffered from motion sickness and $12.0 \%$ suffered from upper digestive tract diseases. Chronic respiratory (8.67\%) and metabolic conditions $(8.67 \%)$ occurred in few respondents. Based on the BMI calculated for each patient, they were qualified into 3 groups: normal body weight (42.7\%), underweight (4.0\%) and overweight (53.3\%).

Table 2 shows data concerning the course of the preoperative and postoperative period. Laparoscopic surgery was performed for $51.0 \%$ of the respondents, laparotomic method was used in $38.0 \%$ of them, and $13.33 \%$ underwent plastic surgery of the genital organs. In 7 cases, a decision about swapping the method from laparoscopy to laparotomy during surgery was made. Endotracheal anaesthesia was given to $59.66 \%$ of the patients, while $42.66 \%$ of them received spinal anaesthesia. Analysing the duration of surgery, $14.33 \%$ lasted more than $2 \mathrm{~h}, 38.0 \%$ lasted no more than $2 \mathrm{~h}, 36.67 \%$ lasted no more than $1 \mathrm{~h}$, and $11.0 \%$ lasted no more than $0.5 \mathrm{~h}$. During anaesthesia, fentanyl was used in $43.99 \%$ of the respondents, fentanyl and morphine was used in $21.52 \%$ of the patients, and spinal morphine was used in $34.49 \%$ of them. As a PONV preventive measure, the women were given Ondansetron (70.67\%), Ondansetron and Dexaven (25.33\%) or Metoclopramid (0.67\%). However, 3.33\% of the respondents were not given any form of pharmaceutical prevention (they were patients who received spinal anaesthesia without spinal morphine). Non-pharmaceutical PONV prophylaxis in the form of chewing gum was used in $49.67 \%$ of women. Most women (77.67\%) did not eat for more than $10 \mathrm{~h}$ prior to surgery, which is inadvisable. The longest withdrawal of drink, also inconsistent with enhanced recovery after surgery recommendation (ERAS), lasted more than $10 \mathrm{~h}(48.0 \%)$. As many as $49.33 \%$ of the patients did not eat for more than $10 \mathrm{~h}$ after surgery, $16.67 \%$ started eating after $10 \mathrm{~h}$, and $15.67 \%$ started eating within $6 \mathrm{~h}$ after surgery. Only $30.33 \%$ of the examined women started drinking within $3 \mathrm{~h}$ after surgery, $20.67 \%$ after $4 \mathrm{~h}$, and $19.67 \%$ after $6 \mathrm{~h}$. The analysis of the course of postoperative period showed that $63.67 \%$ of the respondents declared a lack of nausea. As much as $28.33 \%$ of the respondents experienced nausea on the 1 st day after surgery, and $13.0 \%$ of them on the 2nd day. Moreover, the vast majority of the patients (79.33\%) did not experience vomiting after surgery. This ailment affected $16.33 \%$ of the women on the 1 st day and $7.0 \%$ on the 2 nd day after surgery.

Table 3 shows the results of the $\chi^{2}$ test of the incidence of nausea and vomiting in relation to the preparation for surgery and its course. The analysis showed that there are statistically significant differences between the incidence of nausea and vomiting, and laparoscopy. Women who underwent laparoscopic surgery more seldom experienced nausea and vomiting $(p<0.0001)$. Statistically significant differences were observed between the incidence of nausea and vomiting, and laparotomy $(p<0.0001)$. The occurrence of nausea and vomiting was higher in patients who underwent laparotomy. There were no differences between the incidence of nausea and vomiting, and the surgical method in women who underwent a plastic surgery of the genital organs ( $\mathrm{p}>0.05)$.

It was observed that endotracheal anaesthesia was significantly negatively associated with nausea and vomiting $(p<0.0001)$. The incidence of nausea and the incidence of vomiting were, respectively, 2 and 3 times lower in patients who were given endotracheal anaesthesia. Spinal anaesthesia was also significantly positively associated with the incidence of nausea and vomiting $(\mathrm{p}<0.0001)$. Women who were given spinal anaesthesia suffered from nausea twice as often as the rest of the patients, with vomiting occurring 3 times more frequently.

Nausea and vomiting were neither significantly associated with the use of fentanyl nor fentanyl plus morphine $(p>0.05)$. 
TABLE 1. Socio-demographic and health data of the respondents

\begin{tabular}{|c|c|c|c|}
\hline Residence & $\mathrm{n}=300(\%)$ & Marital status & $n=300(\%)$ \\
\hline rural & $58(19.33)$ & single & $75(25.00)$ \\
\hline urban & $242(80.67)$ & in a relationship & $225(75.00)$ \\
\hline Education & $n=300(\%)$ & Smoking & $n=300(\%)$ \\
\hline vocational & $89(29.67)$ & yes & $78(26.00)$ \\
\hline secondary & $122(40.66)$ & no & $222(74.00)$ \\
\hline higher & $89(29.67)$ & & \\
\hline Socio-economic status & $\mathrm{n}=300(\%)$ & Alcohol consumption & $n=300(\%)$ \\
\hline very good & $25(8.33)$ & none & $69(23.00)$ \\
\hline good & $187(62.34)$ & occasional & $229(76.34)$ \\
\hline satisfactory & $76(25.33)$ & few times a week & $1(0.33)$ \\
\hline unsatisfactory & $12(4.00)$ & every day & $1(0.33)$ \\
\hline Coexisting conditions & $n=300(\%)$ & BMI & $n=300(\%)$ \\
\hline endocrine & $45(15.00)$ & underweight & $12(4.00)$ \\
\hline metabolic & $26(8.67)$ & normal & $128(42.70)$ \\
\hline upper digestive tract & $36(12.00)$ & & \\
\hline respiratory & $26(8.67)$ & & \\
\hline cardiovascular & $120(40.00)$ & & \\
\hline motion sickness & $38(12.70)$ & & \\
\hline none & $115(38.33)$ & & \\
\hline
\end{tabular}

The analysis showed that nausea occurred in $1 / 3$ of the patients, whereas $1 / 5$ of them experienced vomiting. However, there was a highly significant positive relation with the use of spinal morphine $(\mathrm{p}<0.01)$ and administering this drug involved a higher risk of the incidence of nausea and vomiting.

The observation proved that pharmaceutical prevention of PONV did not significantly affect the incidence of nausea and vomiting ( $p>0.05)$, while nausea and vomiting were significantly negatively associated with the use of non-pharmaceutical prevention ( $p<0.01$ and $p<0.05$ respectively). Chewing gum significantly reduced the prevalence of nausea and vomiting.

The analysis of the incidence of nausea and vomiting in relation to the duration of surgery showed that vomiting was significantly associated with the duration of surgery $(p<0.01)$, unlike nausea $(p>0.05)$. A prolonged duration of surgery resulted in more frequent incidence of vomiting.

Table 4 shows the correlation between the incidence of nausea and vomiting, and socio-demographic variables and BMI. No statistical relationships were observed in relation to any variable $(\mathrm{p}>0.05)$.

In Table 5 shows the incidence of nausea and vomiting in relation to tobacco and alcohol consumption. Significant differences were observed between smoking and the occurrence of nausea $(p=0.01)$. Smokers were less likely to experience nausea in the postoperative period. However, there were no such differences in the case of vomiting $(p=0.18)$. Occasional alcohol consumption had no significant effect on experiencing nausea and vomiting by the patients after surgery $(p>0.05)$. 
TABLE 2. Data concerning the course of preoperative and postoperative period

\begin{tabular}{|c|c|c|c|}
\hline Type of surgery & $n=300(\%)$ & Opioids used during anaesthesia & $n=300(\%)$ \\
\hline laparoscopic method & $153(51.00)$ & Fentanyl & $139(43.99)$ \\
\hline laparotomic method & $114(38.00)^{*}$ & Fentanyl + Morphine & $68(21.52)$ \\
\hline plastic surgery of genital organs & 40 (13.33) & Spinal Morphine & $109(34.49)$ \\
\hline endotracheal & $179(59.66)$ & chewing gum & $149(49.67)$ \\
\hline spinal & $128(42.66)$ & without chewing gum & $151(50.33)$ \\
\hline Duration of surgery & $n=300(\%)$ & Pharmaceutical PONV prevention & $\mathrm{n}=300(\%)$ \\
\hline up to $1 \mathrm{~h}$ & $110(36.67)$ & Ondansetron + Dexaven & $76(25.33)$ \\
\hline up to $2 \mathrm{~h}$ & $114(38.00)$ & Metoclopramid & $2(0.67)$ \\
\hline more than $2 \mathrm{~h}$ & $43(14.33)$ & none & $10(3.33)$ \\
\hline Withdrawal of food prior to surgery & $\mathrm{n}=300(\%)$ & $\begin{array}{l}\text { Withdrawal of drink prior } \\
\text { to surgery }\end{array}$ & $\mathrm{n}=300(\%)$ \\
\hline $3 \mathrm{~h}$ & $0(0)$ & $3 \mathrm{~h}$ & $13(4.33)$ \\
\hline $4 \mathrm{~h}$ & $0(0)$ & $4 \mathrm{~h}$ & $4(1.34)$ \\
\hline $5 \mathrm{~h}$ & $0(0)$ & $5 \mathrm{~h}$ & $2(0.66)$ \\
\hline $10 \mathrm{~h}$ & $65(21.67)$ & $10 \mathrm{~h}$ & $124(41.34)$ \\
\hline more than $10 \mathrm{~h}$ & $233(77.67)$ & more than $10 \mathrm{~h}$ & $144(48.00)$ \\
\hline Withdrawal of food after surgery & $\mathrm{n}=300(\%)$ & Withdrawal of drink after surgery & $n=300(\%)$ \\
\hline $3 \mathrm{~h}$ & $5(1.66)$ & $3 \mathrm{~h}$ & $91(30.33)$ \\
\hline $4 \mathrm{~h}$ & $20(6.67)$ & $4 \mathrm{~h}$ & $62(20.67)$ \\
\hline $5 \mathrm{~h}$ & $30(10.00)$ & $5 \mathrm{~h}$ & $37(12.33)$ \\
\hline $6 \mathrm{~h}$ & $47(15.67)$ & $6 \mathrm{~h}$ & $59(19.67)$ \\
\hline $10 \mathrm{~h}$ & $50(16.67)$ & $10 \mathrm{~h}$ & $34(11.33)$ \\
\hline more than $10 \mathrm{~h}$ & $148(49.33)$ & more than $10 \mathrm{~h}$ & $17(5.67)$ \\
\hline Incidence of nausea & $\mathrm{n}=300(\%)$ & Incidence of vomiting & $n=300(\%)$ \\
\hline yes & $109(36.33)$ & yes & $62(20.67)$ \\
\hline no & $191(63.67)$ & no & $238(79.33)$ \\
\hline Incidence of nausea & $\mathrm{n}=300(\%)$ & Incidence of vomiting & $n=300(\%)$ \\
\hline 1st day after surgery & $85(28.33)$ & 1st day after surgery & $49(16.33)$ \\
\hline 2nd day after surgery & $39(13.00)$ & 2nd day after surgery & $21(7.00)$ \\
\hline
\end{tabular}

* in 7 of the operations during laparoscopy, a decision was made to convert to laparotomy 
TABLE 3. The incidence of nausea and vomiting in relation to the type of surgery and anaesthesia, drugs used prior to surgery, duration of surgery and non-pharmaceutical prevention of postoperative nausea and vomiting

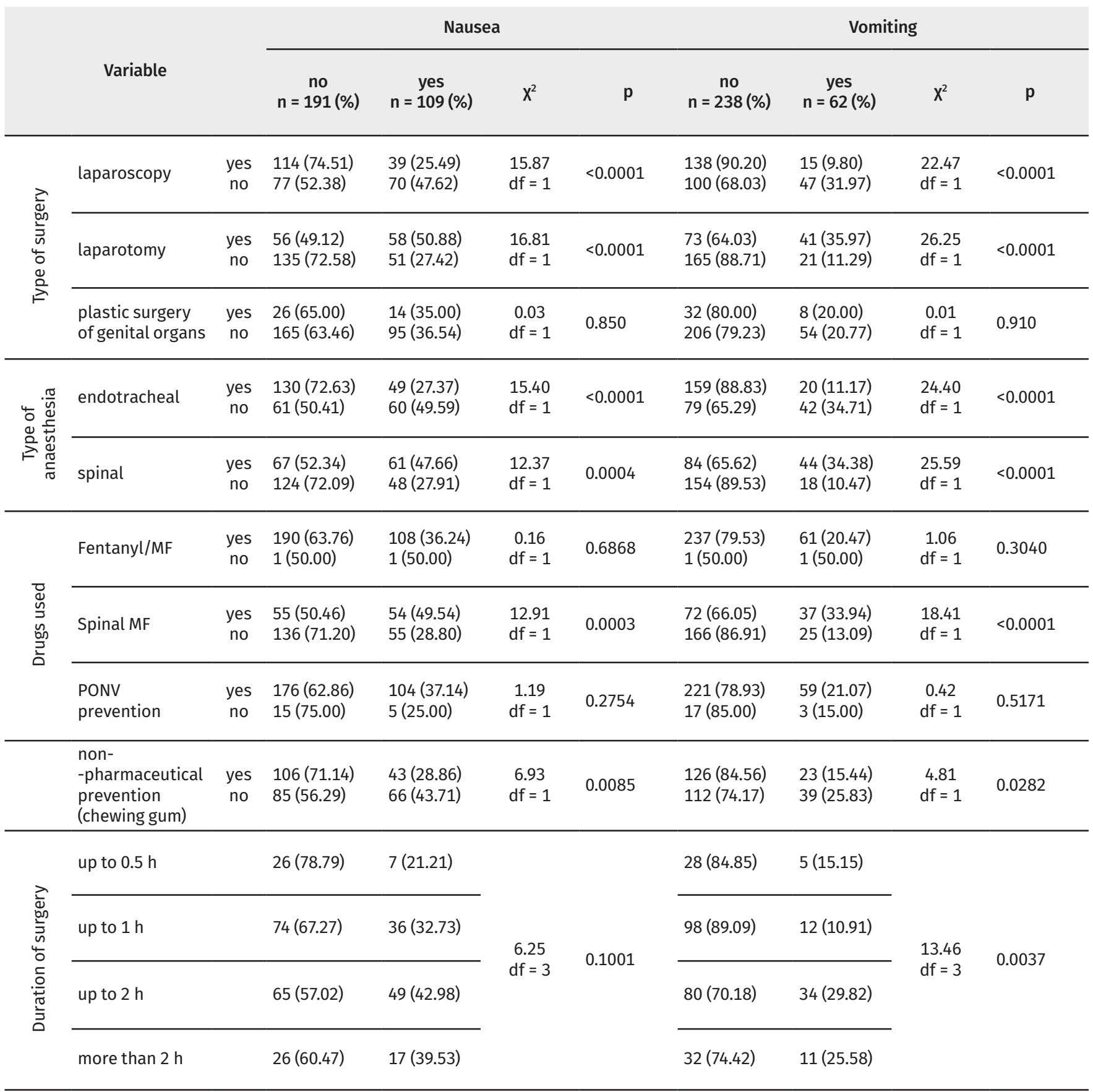

df - statistical significance factor; $p$ - statistical significance

Table 4 shows the correlation between the incidence of nausea and vomiting, and socio-demographic variables and BMI. No statistical relationships were observed in relation to any variable $(p>0.05)$. 
TABLE 4. Correlations between the incidence of nausea and vomiting, socio-demographic variables, BMI and use of stimulants

\begin{tabular}{|c|c|c|c|c|c|c|c|c|c|}
\hline & \multirow[b]{2}{*}{ Variable } & \multicolumn{4}{|c|}{ Nausea } & \multicolumn{4}{|c|}{ Vomiting } \\
\hline & & $\begin{array}{c}\text { no } \\
\mathrm{n}=191(\%)\end{array}$ & $\begin{array}{c}\text { yes } \\
n=109(\%)\end{array}$ & $x^{2}$ & $\mathrm{p}$ & $\begin{array}{c}\text { no } \\
n=238(\%)\end{array}$ & $\begin{array}{c}\text { yes } \\
n=62(\%)\end{array}$ & $x^{2}$ & $p$ \\
\hline \multirow{2}{*}{ ڤั) } & $<50$ years old & $103(66.88)$ & $51(33.12)$ & \multirow{2}{*}{$\begin{array}{c}1.41 \\
d f=1\end{array}$} & \multirow{2}{*}{0.2342} & $129(83.77)$ & 25 (16.23) & \multirow{2}{*}{$\begin{array}{c}3.79 \\
d f=1\end{array}$} & \multirow{2}{*}{0.0515} \\
\hline & $>50$ years old & $88(60.27)$ & $58(39.73)$ & & & $109(74.66)$ & $37(25.34)$ & & \\
\hline \multirow{2}{*}{ 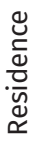 } & urban & $148(61.16)$ & $94(38.84)$ & \multirow{2}{*}{$\begin{array}{c}3.41 \\
d f=1\end{array}$} & \multirow{2}{*}{0.06} & $188(77.69)$ & $54(22.31)$ & \multirow{2}{*}{$\begin{array}{c}2.07 \\
d f=1\end{array}$} & \multirow{2}{*}{0.15} \\
\hline & rural & $43(74.14)$ & $15(25.86)$ & & & $50(86.21)$ & $8(13.79)$ & & \\
\hline \multirow{2}{*}{ 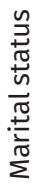 } & single & $53(70.67)$ & $22(29.33)$ & \multirow{2}{*}{$\begin{array}{c}2.12 \\
d f=1\end{array}$} & \multirow{2}{*}{0.1455} & $64(85.33)$ & $11(14.67)$ & \multirow{2}{*}{$\begin{array}{c}2.20 \\
d f=1\end{array}$} & \multirow{2}{*}{0.1384} \\
\hline & in a relationship & $138(61.33)$ & $87(38.67)$ & & & $174(77.33)$ & $51(22.67)$ & & \\
\hline \multirow{3}{*}{$\begin{array}{l}\text { 듬 } \\
\text { 를 } \\
\text { 뮴 }\end{array}$} & higher & $52(58.40)$ & $37(41.60)$ & \multirow{3}{*}{$\begin{array}{c}1.73 \\
d f=2\end{array}$} & \multirow{3}{*}{0.4203} & $73(82.10)$ & $16(17.9)$ & \multirow{3}{*}{$\begin{array}{c}1.33 \\
d f=2\end{array}$} & \multirow{3}{*}{0.5140} \\
\hline & secondary & 79 (64.75) & $43(35.25)$ & & & $98(80.33)$ & $24(19.67)$ & & \\
\hline & vocational & $60(67.40)$ & $29(32.60)$ & & & $67(75.30)$ & $22(24.7)$ & & \\
\hline \multirow{3}{*}{ 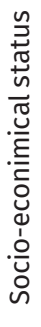 } & very good & $14(56.00)$ & $11(44.00)$ & \multirow{3}{*}{$\begin{array}{c}1.10 \\
d f=3\end{array}$} & \multirow{3}{*}{0.7780} & $22(88.00)$ & $3(12.00)$ & \multirow{3}{*}{$\begin{array}{c}1.67 \\
d f=3\end{array}$} & \multirow{3}{*}{0.6438} \\
\hline & satisfactory & $51(67.11)$ & 25 (32.89) & & & $61(80.26)$ & $15(19.74)$ & & \\
\hline & unsatisfactory & $8(66.67)$ & $4(33.33)$ & & & $10(83.33)$ & $2(16.67)$ & & \\
\hline \multirow{3}{*}{$\sum_{\infty}$} & low & $11(91.70)$ & $1(8.33)$ & \multirow{3}{*}{$\begin{array}{c}4.48 \\
d f=2\end{array}$} & \multirow{3}{*}{0.1065} & $12(100.00)$ & $0(0)$ & \multirow{3}{*}{$\begin{array}{c}3.28 \\
d f=2\end{array}$} & \multirow{3}{*}{0.1937} \\
\hline & normal & $82(64.06)$ & $46(35.94)$ & & & $101(78.90)$ & $27(21.10)$ & & \\
\hline & high & $98(61.30)$ & $62(38.70)$ & & & 125 (78.10) & 35 (21.90) & & \\
\hline
\end{tabular}

df - statistical significance factor; $p$ - statistical significance

Table 6 shows PONV in relation to the incidence of various conditions. Nausea was not significantly associated with any of the analysed conditions ( $p>0.05$ ). However, vomiting was significantly related to metabolic conditions, mainly diabetes $(p<0.01)$. Patients with such diseases experienced vomiting twice as often as the rest of the respondents. Similarly, vomiting was significantly more common in women with lower digestive tract diseases $(\mathrm{p}<0.05)$. In those patients, vomiting occurred 3 times more frequently than in patients with no such conditions. Vomiting was also significantly related to cardiovascular diseases and motion sickness $(\mathrm{p}<0.05)$ and in both cases, vomiting was more common in the examined group.

Table 7 shows the incidence of nausea and vomiting in relation to the withdrawal of food and drink prior to surgery as well as after surgery. Only the withdrawal of food after surgery was significantly associated with nausea and vomiting $(p<0.01)$. A prolonged withdrawal often increased the risk of nausea and vomiting. 
TABLE 5. Incidence of nausea and vomiting in relation to tobacco and alcohol consumption

\begin{tabular}{|c|c|c|c|c|c|c|c|c|c|}
\hline & \multirow[b]{2}{*}{ Variable } & \multicolumn{4}{|c|}{ Nausea } & \multicolumn{4}{|c|}{ Vomiting } \\
\hline & & $\begin{array}{c}\text { no } \\
n=191(\%)\end{array}$ & $\begin{array}{c}\text { yes } \\
n=109(\%)\end{array}$ & $x^{2}$ & $p$ & $\begin{array}{c}\text { no } \\
n=238(\%)\end{array}$ & $\begin{array}{c}\text { yes } \\
n=62(\%)\end{array}$ & $x^{2}$ & p \\
\hline \multirow{4}{*}{ 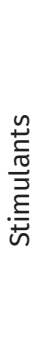 } & smoking tobacco & $59(75.64)$ & $19(24.36)$ & \multirow{2}{*}{$6.53 \mathrm{df}=1$} & \multirow{2}{*}{0.01} & $66(84.62)$ & 12 (15.38) & \multirow{2}{*}{$1.79 \mathrm{df}=1$} & \multirow{2}{*}{0.1805} \\
\hline & $\begin{array}{l}\text { not smoking } \\
\text { tobacco }\end{array}$ & $132(59.46)$ & $90(40.54)$ & & & $172(77.48)$ & $50(22.52)$ & & \\
\hline & drinking alcohol & $147(63.64)$ & $84(36.36)$ & \multirow{2}{*}{$0.00 \mathrm{df}=1$} & \multirow{2}{*}{0.9841} & $186(80.52)$ & 45 (19.48) & \multirow{2}{*}{$0.86 \mathrm{df}=1$} & \multirow{2}{*}{0.3532} \\
\hline & not drinking alcohol & $44(63.77)$ & $25(36.23)$ & & & $52(75.36)$ & $17(24.64)$ & & \\
\hline
\end{tabular}

df - statistical significance factor; $p$ - statistical significance

TABLE 6. Postoperative nausea and vomiting in relation to the incidence of other conditions

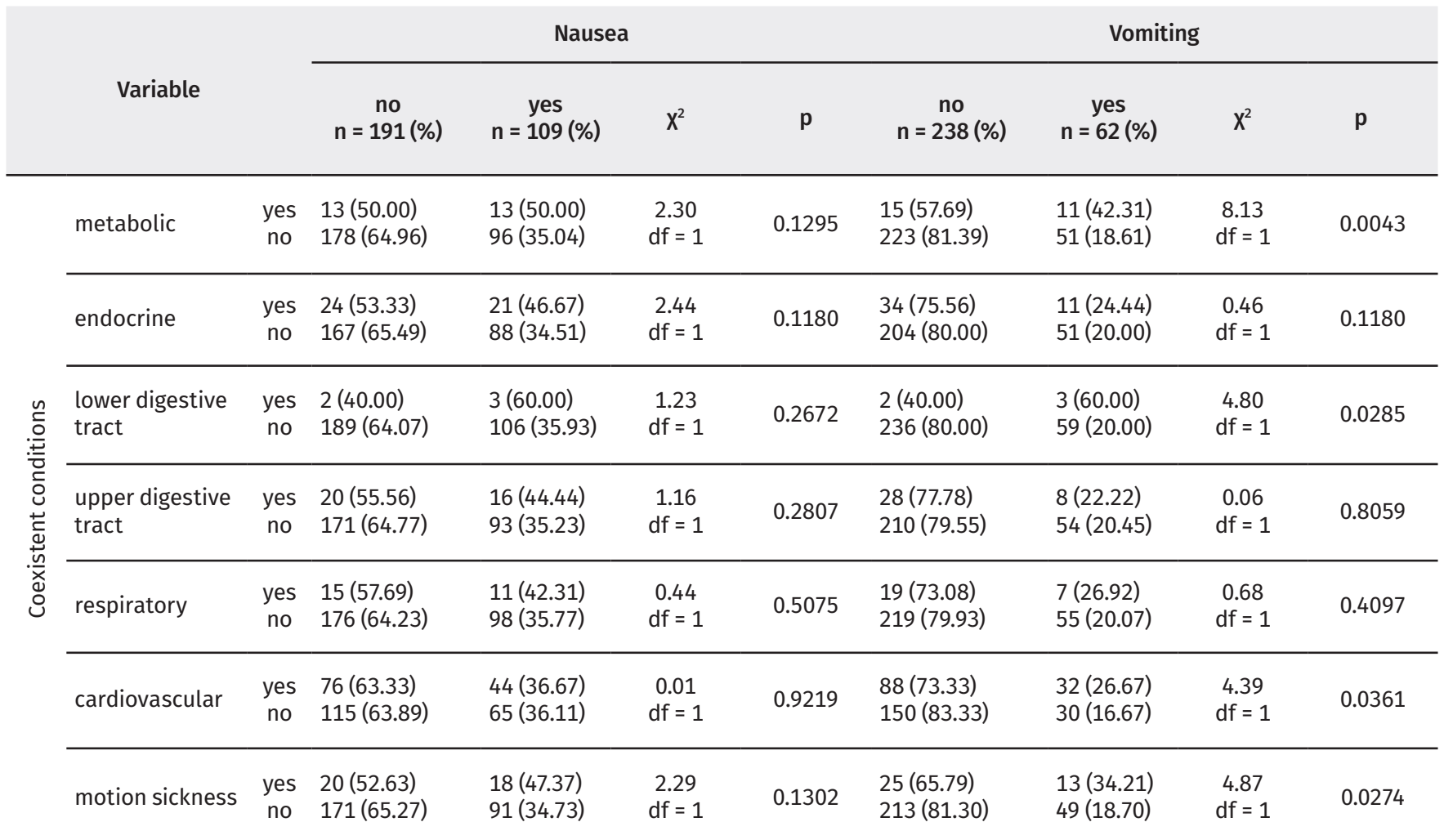

df - statistical significance factor; $p$ - statistical significance 
TABLE 7. The incidence of nausea and vomiting in relation to the withdrawal of food and drink

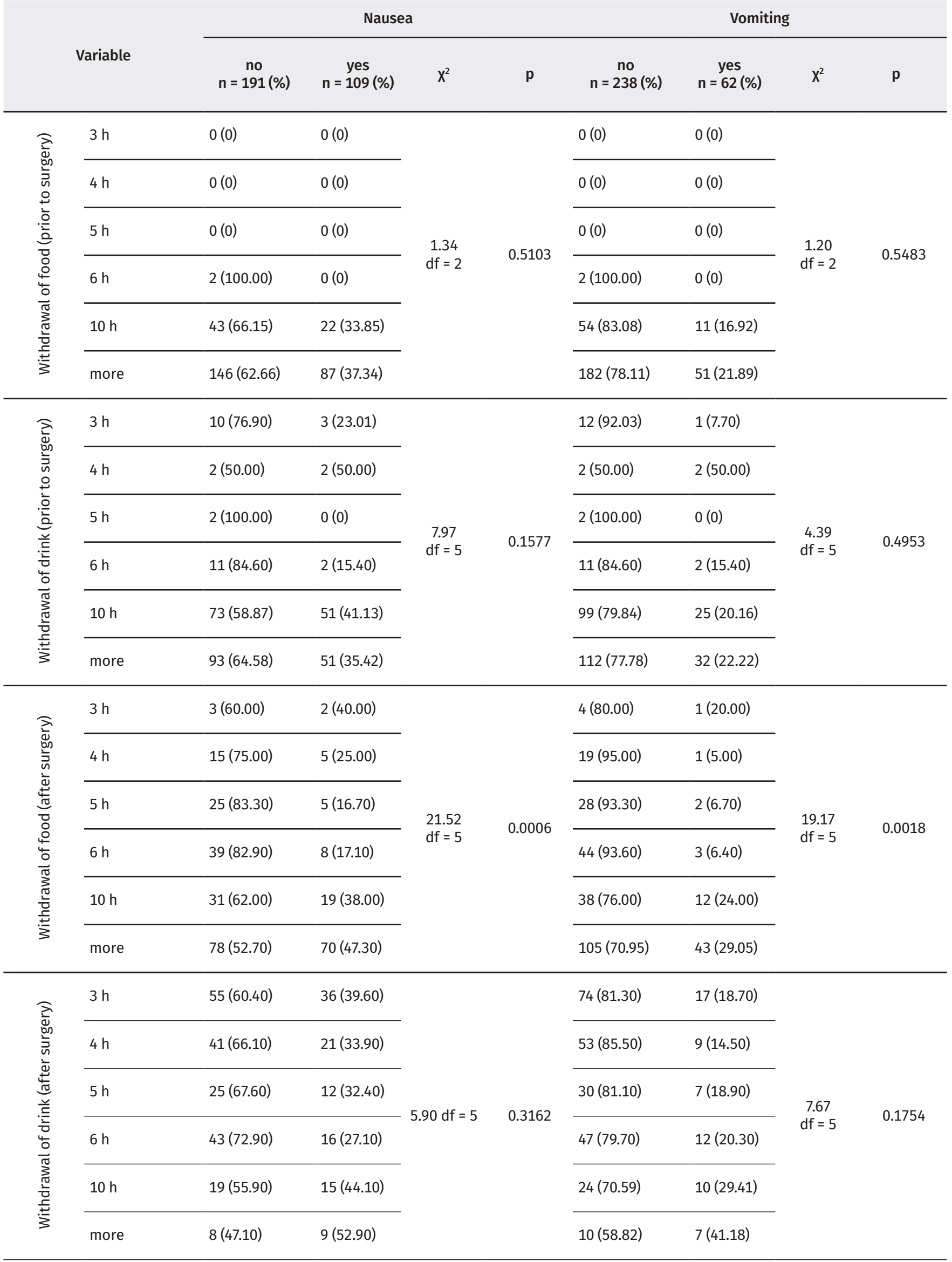

df - statistical significance factor; $p$ - statistical significance 


\section{DISCUSSION}

The main task of the medical team is to ensure patient safety in the perioperative period [5]. Proper anaesthetic and operative management play an important role. Rules of conduct, including a wide range of aspects dealing with patients in the perioperative period from both an anaesthesiological and operative point of view, have been provided by the ERAS guidelines. The Society for Ambulatory Anaesthesia (SAMBA) has also published guidelines concerning PONV, since they are one of the most common complications. These symptoms significantly lower satisfaction from surgery and anaesthesia. According to the Apfel scale, the disorder is present in $20-30 \%$ of the general surgery population and in $70-80 \%$ of the patients in a high risk group [6]. Women undergoing gynaecological surgeries are a particular group of patients because of the increased risk of PONV [7].

Scales and protocols estimating the probability of nausea and vomiting, which in many cases are part of a perioperative anaesthesiological questionnaire, often assist in predicting PONV. The obtained information helps in successful prevention and treatment of these disorders. Preventing complications positively affects not only patients but also hospitals by lowering medical costs and shortening the length of the hospital stay and rehabilitation $[8,9]$.

The factors predisposing PONV include: female sex, age, smoking tobacco, BMI, coexistent diseases (including motion sickness). It is difficult to determine which of the factors are responsible for the incidence of nausea and vomiting and to what degree they are so. In our research, no relation between socio-demographic variables (age, education, marital status, socioeconomic status, place of residence) and the incidence of PONV was observed. It is important to highlight that the group of respondents was homogenous in terms of sex and consisted only of women. Other researchers pay particular attention to the factor of female sex. Studies by Sokół-Kobielska and Muszyński show that vomiting occurred 3 times more often in women than in men [10]. Moreno et al. reported similar results [11].

Many sources indicate obesity as a factor increasing the incidence of PONV since gastric emptying and peristaltic movements of the digestive tract are slower in obese people. Our study showed that patient BMI had no statistically significant effect on the incidence of nausea and vomiting in the postoperative period ( $p>0.05$ ), although they occurred in women with high or normal BMI more frequently than in women with low BMI, where they were practically absent. Studies conducted by Cierzniakowska et al. among obese people showed that BMI did not affect the prevalence of PONV ( $p>0.05)$ [12]. There are other studies suggesting a similar relationship [13].

Abstinence from smoking is a factor that increases the incidence of PONV. Our study shows a significant negative difference between the incidence of nausea and smoking cigarettes $(\mathrm{p}<0.05)$. Smokers experienced nausea in the postoperative period less often than the non-smoking women. In the case of vomiting, there were no similar relationships ( $p>0.05)$.
Søreide et al. [14] and Søreide and Ljungqvist [15] achieved similar results. With reference to ERAS groundwork and guidelines concerning optimal preoperative care, patient health, their biological potential should be enhanced prior to surgery in order to reduce the number of complications. According to ERAS, active smokers should cease smoking one month before surgery [16].

Significant relationships were observed between the incidence of PONV and the surgical method. The highest incidence of PONV was observed in patients treated with laparotomic surgery. The incidence of nausea in those patients was 2 times higher and the incidence of vomiting was 3 times higher than in other women. Grabowska-Gaweł et al. [17] and Lerman [18] achieved similar research results. Cierzniakowska et al. claims that gynaecological laparotomy is one of the factors increasing the risk of PONV [12]. Our study shows that women who underwent laparoscopic surgery experienced nausea and vomiting less frequently $(\mathrm{p}<0.0001)$. In the case of plastic surgery of the genital organs, there was no association with nausea and vomiting ( $p>0.05)$. According to Apfel et al. [9, 19], there is no relationship between the type of surgery and the incidence of PONV. They claim that it is primarily caused by the use of inhalation anaesthetics [19].

There is a significant relationship between the incidence of nausea and vomiting, and the type of anaesthetic used. Our study shows that the type of anesthesia divided the respondents in terms of the incidence of PONV. Nausea and vomiting occurred less frequently after endotracheal anaesthesia $(p<0.01)$. The incidence of nausea and the incidence of vomiting were, respectively, 2 and 3 times lower than in other patients. On the other hand, spinal anesthesia significantly affected the incidence of nausea and vomiting $(p<0.01)$.

It is believed that synthetic opioids cause vomiting, although we can observe an individual tendency to vomit as a reaction to the type and dosage of some drugs. Due to a relatively long life-time, morphine is mentioned 1st in the frequency of causing nausea. Our study shows no significant differences in the incidence of nausea and vomiting, depending on the drug used during endotracheal anaesthesia - fentanyl plus morphine in comparison to administering only fentanyl $(\mathrm{p}<0.05)$. A highly significant relationship was observed in the case of administering spinal morphine during spinal anaesthesia $(p<0.01)$, which resulted in a more frequent incidence of nausea and vomiting. Kortilla achieved similar results in their works [20]. Almost all anesthetics used in the perioperative period have a degree of vomit-inducing properties, which increase the incidence of PONV [17].

The analysis of the results of our research shows that nausea is not associated with the duration of surgery ( $p>0.05)$, whereas vomiting differentiated women in this regard, which was statistically significant $(\mathrm{p}<0.01)$. A prolonged duration of surgery resulted in a more frequent incidence of vomiting.

Pharmaceuticals which limit the incidence of PONV were used as a preventive measure in the studied group of gynecological patients. As regards this prevention, the women were given Ondansetron (70.67\%), Ondansetron and Dexaven 
(25.33\%) or Metoclopramid (0.67\%). However, patients who received spinal anaesthesia without spinal morphine were not given any form of pharmaceutical prevention (3.33\%). Our study shows that nausea and vomiting were not significantly associated with pharmaceutical PONV prevention ( $p>0.05)$. In the research conducted by Sokół-Kobielska and Maruszyński, administering Metoklopramid was not statistically significant, whereas administering high doses of Ondansetron substantially lowered the incidence of vomiting. Combining those 2 drugs delivered the expected result as there was no incidence of vomiting [10]. Morończy and Krasnodębski [21] and Olender and Durlik [22] achieved similar results.

Postoperative nausea and vomiting can lead to postoperative intestinal obstruction. Research done by Noble et al. [23] proves that introducing chewing gum after surgery lowers the incidence of postoperative intestinal obstruction by imitating the presence of food in patient's mouth, stimulating bowel movement, and activating gastrointestinal reflex, secretion of gastric juices and production of neurohormonal mediators [21, 22]. In our study, almost half of the women were given chewing gum $(49.67 \%)$. The rest of the respondents $(50,33 \%)$ did not receive this form of prevention due to their age (min. 18-years-old, max. 88-years-old). Using dentures was an excluding factor. Our study shows that chewing gum limits the incidence of nausea and vomiting, which significantly differentiates the respondents ( $\mathrm{p}<0.01, \mathrm{p}<0.05)$. Grzechnik and Godzisz achieved similar results [24]. Morończyk and Krasnodębski stress the beneficial influence of chewing gum on the postoperative period $[21,22]$. Thus, it seems to be appropriate to introduce this element into the postoperative care. It should be noted that it is a low-cost undertaking.

The conducted research shows no significant differences between the incidence of nausea and coexisting diseases $(p>0.05)$. However, vomiting occurred more frequently in the presence of metabolic diseases, mainly diabetes $(\mathrm{p}<0.01)$, and lower digestive tract diseases, cardiovascular diseases and motion sickness ( $\mathrm{p}<0.05)$. Sokół-Kobielska and Maruszyński [10] and Grabowska-Gaweł et al. [17] both mention that motion sickness increases the risk of PONV, which was confirmed by our study.

According to the guidelines of the European Society of Anaesthesiology, withdrawal of solid food and clear fluids before surgery should last $6 \mathrm{~h}$ and $2 \mathrm{~h}$, respectively. Our study shows that as many as $77.67 \%$ of the respondents did not eat for more than $10 \mathrm{~h}$ before surgery, and in most cases (95.67\%) withdrawal of drinks lasted for more than $4 \mathrm{~h}$. Such behaviour was inconsistent with the guidelines of the European Society of Anaesthesiology and ERAS programme. A prolonged withdrawal of drink leads to dehydration which subsequently intensifies PONV. Beverages rich in carbohydrates are beneficial in the postoperative period but serving them is an infrequent practice in Polish hospitals. Gustafsson et al. [16] and Nikodemski [25] claim that beverages rich in carbohydrates have a positive impact on patients. Proper duration of the withdrawal of food after surgery depends on its extent, thus not allowing for unambiguous and precise rules. However, it is recommended to start postoperative feeding as early as possible. Postoperative fasting was apparent in our study, as $49.33 \%$ of the respondents did not eat for more than $10 \mathrm{~h}$ after surgery, contrary to the satisfactory withdrawal of drink after surgery (30.33\% of the respondents drank within $3 \mathrm{~h}$ after surgery). Studies show that almost half of all surgical patients are undernourished and dehydrated in the perioperative period $[21,22]$. The observed duration of the withdrawal of food after surgery in our study was associated with the incidence of nausea and vomiting. A prolonged withdrawal increased the risk of nausea and vomiting, which highly differentiated the respondents $(\mathrm{p}<0.01)$.

Implementing the recommendations as well as introducing standards and procedures that force their complete implementation are major issues in clinical practice because evidence-based medicine and evidence-based nursing practice will ensure patient safety, high quality care and patient satisfaction. Despite the existence of worldwide guidelines concerning the postoperative care of patients undergoing planned surgery, it appears that they are not implemented into routine procedures. Programmes that improve the health status and recovery of patients after surgery should have a place in the organisational structures of units, whereas education should not only cover patients but also their families and their therapeutic team as part of regular trainings.

\section{CONCLUSIONS}

1. The type and duration of surgery as well as the type of anaesthesia and opioids used affected the incidence of nausea and vomiting in the postoperative period. If possible, every effort should be made to shorten the duration of surgery, perform surgery laparoscopically and administer drugs which do not affect the incidence of nausea and vomiting.

2. There is a need for organisational changes in hospitals regarding the introduction and compliance with ERAS, in particular, with regard to the withdrawal of food and drink before and after surgery.

3. The use of chewing gum strongly reduced the incidence of nausea and vomiting. Therefore, it would be important to introduce, as a standard practice, this non-pharmacological prevention method in the postoperative period.

\section{REFERENCES}

1. McCaffrey R. Make PONV prevention a priority. OR Nurse J 2007;1:39-45.

2. Gan TJ. Postoperative nausea and vomiting - can it be eliminated? JAMA 2002;287(10):1233-6.

3. Habib AS, Chen YT, Taguchi A, Hu XH, Gan TJ. Postoperative nausea and vomiting following inpatient surgeries in a teaching hospital: a retrospective database analysis. Curr Med Res Opin 2006;22(6):1093-9.

4. Horn CC, Wallisch WJ, Homanics GE, Williams JP. Pathophysiological and neurochemical mechanisms of postoperative nausea and vomiting. Eur J Pharmacol 2014;722:55-66.

5. Misiołek H. Ogólne zasady monitorowania i terapii w bezpośrednim okresie pooperacyjnym. In: Karpel E, Jałowiecki P, editors. Ogólne powikłania pooperacyjne. Warszawa: Wydawnictwo Lekarskie PZWL; 2009. p. 45-58. 
6. Kübler A. Anestezjologia i intensywna terapia - postępy. Med Prakt Chir 2008;3:51-6.

7. Yoong W, Sivashanmugarajan V, Relph S, Bell A, Fajemirokun E, Davies T, et al. Can enhanced recovery pathways improve outcomes of vaginal hysterectomy? Cohort control study. J Minim Invasive Gynecol 2014;21(1):83-9.

8. Gan TJ. Mechanisms underlying postoperative nausea and vomiting and neurotransmitter receptor antagonist-based pharmacotherapy. CNS Drugs 2007;21(10):813-33

9. Apfel CC, Philip BK, Cakmakkaya OS, Shilling A, Shi YY, Leslie JB, et al. Who is at risk for postdischarge nausea and vomiting after ambulatory surgery? Anesthesiology 2012;117(3):475-86.

10. Sokół-Kobielska E, Maruszyński M. Zapobieganie nudnościom i wymiotom po operacjach laparoskopowych. Videochirurgia 1996;1/2:22-5.

11. Moreno C, Veiga D, Pereira H, Martinho C, Abelha F. Postoperative nausea and vomiting: incidence, characteristics and risk factors - a prospective cohort study. Rev Esp Anestesiol Reanim 2013;60(5):249-56.

12. Cierzniakowska K, Szewczyk MT, Kozłowska E, Wyborna R, Popow A, Mościcka P, et al. Ocena występowania nudności i wymiotów u chorych po zabiegu chirurgicznym. Pielęg Chir Angiol 2014;1:15-23.

13. Kranke P, Apefel CC, Papenfuss T, Rauch S, Löbmann U, Rübsam B, et.al. An increased body mass index is no risk factor for postoperative nausea and vomiting. A systematic review and results of original data. Acta Anaesthesiol Scand 2001;45(2):160-6.

14. Søreide E, Holst-Larsen H, Veel T, Steen PA. The effects of chewing gum on gastric content prior to induction of general anesthesia. Anesth Analg 1995;80(5):985-9.

15. Søreide E, Ljungqvist O. Modern preoperative fasting guidelines: a summary of the present recommendations and remaining questions. Best Pract Res Clin Anaesthesiol 2006;20(3):483-91.
16. Gustafsson UO, Scott MJ, Schwenk W, Demartines N, Roulin D, Francis N, et al. Wytyczne dotyczące opieki okołooperacyjnej u chorych operowanych planowo z powodu chorób jelita grubego: zalecenia Towarzystwa ERAS-część 1. Postępy Żywienia Klinicznego 2013;3(27):40-7.

17. Grabowska-Gaweł A, Porzych K, Piskunowicz G. Czynniki ryzyka i częstość występowania pooperacyjnych nudności i wymiotów u chorych operowanych w znieczuleniu ogólnym. Prz Lek 2006;63(2):72-6.

18. Lerman J. Surgical and patient factors involved in postoperative nausea and vomiting. Br J Anaesth 1992;69(7 Suppl 1):24S-32S.

19. Apfel CC, Greim CA, Haubitz I, Goepfert C, Usadel J, Serafin P, et al. A risk score to predict the probability of postoperative vomiting in adults. Acta Anaesthesiol Scand 1998;42(5):495-501.

20. Kortilla K. The study of postoperative nausea and vomiting. Br J Anaesth 1992;62:20S.

21. Morończy DSF, Krasnodębski IW. Fast track surgery (szybka ścieżka chirurgiczna) ze szczególnym uwzględnieniem chorych poddanych zabiegom resekcyjnym jelita grubego. Pol Prz Chir 2001;1:92-104.

22. Olender P, Durlik M. Zasady stosowania leczenia żywieniowego u pacjentów na oddziale chirurgicznym. Prz Gastroenterol 2006;1(3):151-7.

23. Noble EJ, Harris R, Hosie KB, Thomas S, Lewis SJ. Gum chewing reduces postoperative ileus? A systematic review and meta-analysis. Int J Surg 2009;7(2):100-5.

24. Grzechnik K, Godzisz M. Żucie ratuje życie, czyli guma do żucia jako profilaktyka pooperacyjnej niedrożności jelit. 2015. https://medtube.pl/ tribune-pl/2015/03/zucie-ratuje-zycie-czyli-guma-do-zucia-jako-profilaktyka-pooperacyjnej-niedroznosci-jelit/ (13.06.2018).

25. Nikodemski T. Przyspieszona rekonwalescencja. Pielęgniarstwo anestezjologiczne i intensywnej opieki - wybrane aspekty postępowania. Część II. 2012. p. 224-31. 